Morgan, J. (2013). Imperium Book 3. Princeps: Volume 3. CreateSpace Independent Publishing Platform.

Quirk, R. S., Greenbaum, G., Leech, G., Svartvik, J. (1985). A Comprehensive Grammar of the English Language. London: Longman.

Ruppel, A. (2013). Absolute constructions in early Indo-European. New York: Cambridge University Press.

Sakakibara, H. (1982). WITH-constructions in English. Studies in English Literature, Tokyo: English Literary Society of Japan, 79-95.

Talmy, L. (1978). Figure and ground in complex sentences. Universals of human language. Stanford: Stanford University Press, Vol. 4, 627-649.

Thompson, S. A., Longacre, R. E., Hwang, J. J. (2007). Adverbial clauses. Language Typology and Syntactic Description. Vol. II: Complex constructions. Ed. T. Shopen, Cambridge: Cambridge University Press, 237-300.

Thompson, S. A. (1983). Grammar and discourse: The English detached participial clause. Discourse perspectives on syntax. New York: Academic Press, 43-64.

Visser, F. Th. (1972). An Historical Syntax of the English Language. Part II: Syntactical Units With One Verb. Leiden: E.J. Brill.

Wasserscheidt, Ph. (2012). Construction Grammar: Basic Principles and concepts. Ukrainske movoznavstvo, T. 49, 94-116.

Westin, I. (2002). Language Change in English Newspaper Editorials. Amsterdam, New York: Ropdopi.

Wheelock, F. M., LaFleur, R. A. (2005). Wheelock's Latin (6 ${ }^{\text {th }}$ ed.). New York: HaperCollins.

Zandvoort, R. W. (1975). A Handbook of English Grammar ( $7^{\text {th }}$ ed.). London: Longman.

\title{
VARIABLY-INTERPRETIVE POTENTIAL OF THE LITERARY TEXT AND ITS REALIZATION IN THE TRANSALTION (BASED ON CHUCK PALAHNIUK'S NOVEL "FIGHT CLUB") \\ ВАРІАТИВНО-ІНТЕРПРЕТАЦЙНИЙ ПОТЕНЦАЛ ХУДОЖНЬОГО ТВОРУ ТА ЙОГО РЕАЛІЗАЦІЯ У ПЕРЕКЛАДІ (НА ОСНОВІ РОМАНУ ЧАКА ПОЛАНІКА "БІЙЦІВСЬКИЙ КЛУБ")
}

\author{
Анна ЗАДОРОЖНА, Василь БЯЛИК \\ Чернівецький національний університет імені Юрія Федьковича \\ zadorozhna.anna@chnu.edu.ua, v.bialyk@chnu.edu.ua \\ ORCID ID 0000-0002-8571-5296, ORCID ID 0000-0001-7428-7145
}

The article examines the variability of translation of the text of fiction as performed by different translators. The purpose of the work is to study and identify the diversity of the translation strategies and features of their application in the translation of a literary text. The method of comparative analysis proved to be effective in the scientific investigation. The subject of the research is a literary text, its original and translation. The postulates of translation theorists on linguistic variability and multiplicity of translations have been outlined. The subjective-objective activity of the translator as a mediator in bilingual communication was highlighted. The peculiarities of Chuck Palahniuk's writing style have been determined and the preservation of the author's individual style in Ukrainian translations has been analyzed. A comparative analysis of fragments of the translation of the literary text made by Ukrainian translators has been carried out. It was discovered that in the process of translation the translator relies not only on his knowledge of the languages, but also on the general knowledge of other areas of human life. It has been established that the perception and understanding of the text by the recipients depends on how the translator interprets the text of the original and how adequately s/he conveys its context and whether s/he is able to preserve the author's style. The study was based on the novel "Fight Club" by the contemporary American writer Chuck Palahniuk and its translations into Ukrainian by Illia Strongovskyi and Oleh Lesko. It has been proved 
that translations made into the same language by different translators can differ significantly from each other.

Key words: translation multiplicity, translator's position, translation strategy, variability, translation studies.

Статтю присвячено вивченню відмінностей перекладацьких тактик, застосованих різними перекладачами при перекладі одного й того ж твору. Мета роботи полягає у дослідженні та виявленні різноманітності спектру перекладацьких стратегій та особливостей їх застосування у процесі перекладу художнього твору. Під час дослідження було застосовано метод порівняльного аналізу та зіставний метод. Предметом дослідження $є$ художній твір в оригіналі та перекладі. У роботі також визначено причини виникнення кількох варіантів перекладу художнього твору. Проаналізовано дослідження теоретиків перекладознавства стосовно мовної варіативності й множинності перекладів. Висвітлено суб'єктивно-об'єктивну діяльність перекладача як посередника у двомовній комунікації. Розглянуто особливості письменницького стилю Чака Поланіка та проаналізовано збереження індивідуального стилю автора у перекладах на українську мову. Проведено порівняльний аналіз фрагментів перекладу художнього твору, здійсненого українськими перекладачами. Виявлено, що у процесі перекладу перекладач спирається не лише на свої досконалі знання мов оригіналу та перекладу, а й на загальні знання з інших сфер людського життя. Встановлено, що від того, як перекладач інтерпретуватиме текст оригіналу та наскільки адекватно передасть його суть і чи зможе зберегти стиль автора, залежатиме сприйняття та розуміння твору реципієнтами тієї культури, на яку здійснено переклад. Матеріалом дослідження було обрано роман сучасного американського письменника Chuck Palahniuk "Fight Club" і його переклади українською мовою, виконані І. Стронговським та О. Леськом. Розглянуто випадки повторюваності у перекладах та їх цілковитої відмінності, пов'язаної із різницею інтерпретації тексту, різноманітністю застосованих перекладацьких тактик та суб'єктивністю трактування тих чи інших особливостей стилю автора оригінального тексту. Встановлено, що, не зважаючи на єдиний текст оригіналу, його переклади, виконані на одну мову різними перекладачами у різний період часу, можуть суттєво відрізнятися один від одного.

Ключові слова: множинність перекладу, перекладацька позиція, стратегія перекладу, варіативність, перекладознавство.

Вступ. Художній переклад спрямований на інтерпретацію навколишньої дійсності, розширення колективної пам'яті людства та подолання міжмовних та міжкультурних бар'єрів. У процесі перекладу художніх текстів головна складність для перекладача полягає в тому, що йому необхідно передати не тільки зміст твору, а й емоційний відтінок тексту і стиль самого автора. Це вимагає наявності мовної компетентності з декількох мов, принаймні двох, та певних фонових знань, які убезпечили б можливість адекватного перекладу художнього твору.

Наукова новизна дослідження полягає у спробі проведення порівняльного аналізу перекладів художнього твору, репрезентованого романом Чака Поланіка "Бійцівський клуб", з англійської на українську мову.

Актуальність дослідження значною мірою зумовлена потребою виявлення оптимальних шляхів адекватності перекладу художнього твору, повноцінного критичного аналізу першотвору й перекладу під час їх зіставлення, а також зростаючою увагою перекладознавців до варіантологічних аспектів художнього перекладу, необхідністю всебічного аналізу образно-змістової, образно- 
формальної інформації і потребою дослідити шляхи реконструкції цієї інформації у перекладі різними перекладачами.

У сучасному глобалізованому світі переклад слід розглядати як необхідну умову для здійснення міжкультурного обміну. Задля його реалізації переклад має бути не тільки адекватним, а й справляти на читача ідентичне до оригіналу враження. Кілька перекладів дають можливість краще зрозуміти оригінальний твір, адже кожен з них по-своєму робить акцент на ключових моментах, завдяки чому загальна суть твору розкривається по-новому. Саме тому важливим $\epsilon$ дослідження та аналіз відмінностей у текстах перекладу (далі ТП) задля кращого розуміння тексту оригіналу (далі ТО).

Питання перекладацької множинності завжди привертало увагу дослідників, адже у всі часи існувало кілька спроб перекладу певного твору, що і спонукало до дослідження виникнення його варіативності (Андрієнко Т. П., Бархударов Л. С., Богін Г. І., Гарбовський М. К., Голоцукова Ю. О., Коміссаров В. Н., Лєвін Ю. Д., Ньюмарк П., Попова О. В., Рильський М. Т., Ребрій О. В., Ситар Р. А., Топер П. М. та інші).

Перекладач володіє не лише білінгвістичними здібностями, а й бікультурним баченням. Він здійснює посередницьку діяльність між культурами (у тому числі й ідеологіями, моральними системами та соціально-політичними структурами), прагнучи подолати несумісність, яка перешкоджає передачі змісту. Те, що має значення в одній культурі, може бути позбавлене сенсу в іншій, і саме перекладач має унікальну можливість виявити невідповідність та знайти шляхи для вирішення цієї проблеми (Bialyk, 2016, c. 62).

Цілком природним $є$ існування у певній культурі кількох перекладів одного й того ж літературного твору. Відомий український письменник та перекладач М. Рильський $(1975$, с. 79) зазначає, що "кожен перекладач може при вдалому взагалі відтворенні іншомовного оповідання, п'єси, поеми, вірша і т. ін. проминути ту чи іншу рису оригіналу, наголосивши, зате на іншій, яка здається йому найістотнішою. Кожен перекладає по-своєму".

Існує безліч точок зору стосовно причин виникнення множинності перекладу та участі перекладача у цьому процесі. Так, лінгвісти у своїх теоретичних працях, присвячених перекладу, розглянули цей феномен у наступних аспектах: "формально-семантичної міжмовної асиметрії" (Кашкин, 2009, с. 32); "неоднорідності способів вербалізації того ж самого відрізку досвіду різними суб'єктами, як в плані виділення послідовності подій, їх учасників та взаємовідносин між ними, так і в плані підбору лексичних одиниць і граматичних структур" (Минченков, 2007); "встановлення прагматично задовільного відношення перекладу, теоретично не одиничного, а одного 3 множини альтернативних, як ізоморфізму, який має місце між різними системами та гарантує комунікацію носіїв мови" (Павиленис, 1983, с. 98); "множинності рішень у межах адекватного перекладу" (Ревзин, 1964, с. 163); "неодиничності перекладацьких рішень" (Швейщер, 1973, с. 71).

Розглядаючи процес перекладу як трансформацію тексту оригіналу в текст перекладу, I. І. Рєвзін і В. Ю. Розенцвейг виокремлюють два шляхи здійснення такого перетворення: "власне переклад", у рамках якого відбувається 
формальний перехід від одиниць однієї мови до одиниць іншої мови, й "інтерпретацію", коли перекладач спочатку усвідомлює, яка дійсність стоїть за одиницями мови в оригіналі, а потім описує цю дійсність засобами мови перекладу (Розенцвейг, 1983 , с. 93).

П. Ньюмарк $(2003$, c. 22) також розглядав проблеми перекладу з точки зору проблеми розуміння та інтерпретації тексту: "Залежно від того, як ви зрозумієте текст оригіналу, ви будете його відображати у тексті перекладу. Особливо це стосується текстів, що містять у собі можливість двоякого тлумачення, тобто це переважно стосується художніх текстів". Ця можливість і визначає виникнення великої кількості варіантів перекладу одного і того ж тексту в залежності від того які перекладацькі стратегії буде використовувати перекладач.

Саме від особистості перекладача та його перекладацьких позицій і залежить те, яким постане перед читачами ТП. За словами У. Еко (2004, c. 72), кожний художній текст "вимагає очевидної співпраці читача". Цілком очевидним є те, що перекладач виступає у ролі читача твору, який має на меті перекласти, а також, у певній мірі, стає і співавтором твору. Адже його інтерпретація змісту та подальша передача сенсу на мову перекладу буде впливати на сприйняття тексту реципієнтами культури перекладу. Зважаючи на це, робота перекладача є такою ж важливою, як і робота письменника, який написав сам твір.

Мета статті полягає у виявленні відмінностей перекладацьких позицій у процесі перекладу художнього твору на прикладі роману американського письменника Чака Поланіка "Бійцівський клуб" у перекладах О. Леська та I. Стронговського.

Для досягнення поставленої мети необхідно вирішити такі завдання:

- розглянути особливості письменницького стилю Чака Поланіка та проаналізувати збереження індивідуального авторського стилю у перекладах на українську мову;

- встановити причини варіативності перекладу одного й того ж твору;

- здійснити порівняльний аналіз фрагментів перекладу художнього твору.

Методи дослідження. Основним методом дослідження є порівняльний аналіз тексту оригіналу та текстів перекладу, застосований для встановлення способів перекладу характерних особливостей стилю письменника з англійської на українську мову.

Результати та обговорення. На переклад та на інтерпретацію тексту впливають об'єктивні і суб'єктивні чинники, серед яких: особливості особистості інтерпретатора, стиль автора та перекладача, жанрові й типологічні особливості ТО і ТП, відмінності культур.

Згідно зі словами Г. Богіна $(1996$, c. 2), "розуміння цілого тексту має тенденцію до свободи: немає двох абсолютно однакових розумінь одного і того ж твору". Саме це дає нам можливість розглянути та порівняти переклади роману "Бійцівський клуб" українською мовою.

Приклад відмінностей перекладів двох перекладачів знаходимо одразу ж на обкладинках книг. Прізвище автора роману "Бійцівський клуб" I. Стронговський (2007) перекладає "Палагнюк", а О. Лесько (2017) надає перевагу варіанту "Поланік". Причина використання різних варіацій перекладу 
одного прізвища полягає у тому, що американський письменник має українське походження, i тому I. Стронговський вдався до методу транскрипції. Проте у одному із інтерв'ю автор наголосив, що його прізвище слід вимовляти "Paulanick", тобто "Поланік"(https://www.theguardian.com/international).

Твори Чака Поланіка спроектовані на сучасний лінгво-культурний простір і вирізняються своєю своєрідністю з-поміж робіт інших американських та світових письменників. Автор називає жанр своїх романів трансгресивною прозою. Цей жанр літератури описує порушення героями норм, стереотипів i соціальних табу, що формуються суспільством, також психоделічні досліди i змінені стани свідомості, як способи вийти за межі норми. Герої практично постійно знаходяться у стані нав'язливої рефлексії, проводять експерименти над своїм сприйняттям світу, піддаючи і свою свідомість різноманітним дослідам. Так вони намагаються визначити, а потім знищити існуючі межі між дозволеним i забороненим, реальністю i божевіллям, поганим i хорошим. У жанрі трансгресивної літературі немає повністю позитивних чи повністю негативних героїв (Кубатченко, 2008).

Однією із характерних ознак жанру трансгресивної літератури є рефрени, котрими пронизаний твір Поланіка. Упродовж усього роману повтори викликають у читачів відчуття чогось якоїсь нав'язливої ідеї, що зв'язує воєдино цілий твір. Повтори рядків у своїх творах Чак Поланік (2006, p. 213) називає "choruses" ("приспіви"). Ці "приспіви" можна назвати однією із найхарактерніших особливостей стилю Чака Поланіка, позаяк цей прийом з'являється у більшості його творів. У одному зі своїх інтерв'ю Чак Поланік (http://bookotron.com/) говорить про функцію повторів: "Це спосіб підтвердити попередні витки сюжету ... Ти перетворюєш їх у повторення або фразу, а потім просто повертаєшся до всіх емоцій того попереднього моменту, викликаних цією справді короткою фразою. Люди роблять це у звичайному житті, і я роблю це у своїх творах".

Найяскравішим прикладом рефренів є правила бійцівського клубу. Розглянемо варіанти перекладу цих правил на українську мову О. Леськом та I. Стронговським:

You don't talk about fight club (Palahniuk, 2006, p. 48).

Tи не говориш про бійцівський клуб (Палагнюк, 2007, с. 63).

Не говорити про бійцівський клуб (Поланік, 2017, с. 55).

Наведені приклади демонструють нам певні відмінності у перекладі. Так, I. Стронговський дослівно перекладає це правило, залишаючи пряме звернення чи то до кожного з учасників клубу, чи до самого читача. У той час як О. Лесько перекладає звернення інфінітивною конструкцією. Для автора важливим є вплив безпосередньо на реципієнта, тому збереження конструкції при перекладі є необхідним.

Головний герой твору страждає від безсоння i все, що відбувається навкруги для нього лише "копія копії копії" (Палагнюк, 2007, с. 19). Для того, щоб викликати схожі почуття у читача, Поланік використовує повтори, коли розповідає про подорожі свого персонажа:

You wake up at Krissy Field (Palahniuk, 2006, p. 28).

Ти прокидаєшся в Кріссі Філд (Палагнюк, 2007, с. 31).

Ти прокидаєшся в аеропорту Кріссі-Філд (Поланік, 2017, с. 31). 
You wake up at Logan (Palahniuk, 2006, p. 25).

Ти прокидаєшся в Логані (Палагнюк, 2007, с. 26).

Ти прокидаєшся в аеропорту імені Логана (Поланік, 2017, с. 27).

Цей приклад демонструє нам переклади культурних реалій, а саме назв аеропорту у Сан-Франциско та Бостоні. У другому варіанті перекладач вдається до прийому додавання, щоб читачу було зрозуміло про що йде мова. У першому ж варіанті речення перекладу еквівалентне реченню оригіналу, однак перекладач додає примітку, в якій пояснює значення "Кріссі Філд" та "Логан", а саме "Аеропорт Сан-Франциско", "Аеропорт Бостона" (Палагнюк, 2007, с. 26, 31). Оскільки, заради збереження ефекту рутини, у тексті наявна велика кількість схожих речень, то вважаємо недоцільним використання приміток для перекладу кожної назви аеропорту.

You just have to watch out for the members of Project Mayhem (Palahniuk, 2006, p. 197).

Ти просто маєш стерегтися учасників проекту "Каліцтво" (Палагнюк, 2007, c. 302).

Тобі просто треба стерегтись інших учасників проекту "Руӥна" (Поланік, 2017, c. 228).

У цьому прикладі ми спостерігаємо варіанти перекладу назви проекту, створеного героєм роману для зруйнування сучасної цивілізації. Враховуючи призначення проекту та дії, вчинені його учасниками, на нашу думку, варіант "проект Руїна" краще передає його суть.

Характерним для стилю Чака Поланіка $є$ введення дієслів для надання тексту більшої динаміки й ритмічності. Наприклад:

Bob's shoulders inhale themselves up in a long draw, then drop, drop, drop in jerking sobs. Draw themselves up. Drop, drop, drop. Bob says and inhales and sob, sob, sobs (Palahniuk, 2006, p. 17).

Плечі Боба підіймаються в глибокому вдихові, а потім cnadaюmb, cnadaюmb, сnадають у конвульсивних схлипах. Підіймаються. Cnadaюmb, спадають, спадають (Палагнюк, 2007, с. 12).

Боб вдихає повітря, його плечі високо здіймаються, а потім опадають уривчастими схлипами. Здіймаються. Опадають. Хлип. Хлип. Хлип (Поланік, 2017, c. 16).

У цьому прикладі дієслова $\epsilon$ засобом створення художнього образу. Триразове повторення дієслів "drop" i "sob" візуалізують емоційний стан персонажа, відтворюючи звуки плачу. І. Стронговському вдається передати цей образ, використовуючи повтори, однак, він, з якихось причин, опускає останнє речення, яке насправді $\epsilon$ ключовим. О. Лесько ж описово передає повторюваність звуків у першій частині та вдало використовує прийом звуконаслідування у кінці речення.

"This isn't really death, "Tyler says. "We'll be legend. We won't grow old." (Palahniuk, 2006, p. 11).

"Насправді це не смерть, - каже Тайлер. - Ми увійдемо в легенди. Ми ніколи не будемо старими" (Палагнюк, 2007, с. 5). 
- Це несправжня смерть, - мовить Тайлер. - Ми станемо легендою. Будемо вічно молодими (Поланік, 2017, с. 11).

Цей фрагмент репліки одного із героїв твору видається цікавим у зв'язку із різними підходами перекладачів до перекладу. Так, при перекладі частини "This isn't really death" I. Стронговський використовує ті ж частини мови, що й автор, змінюючи лише їх порядок у реченні, на той, який є прийнятним для норм української мови. О. Лесько, зі свого боку, використовує аджективізацію, завдяки чому значення фрази дещо змінюється.

Переклад наступної фрази персонажа "We'll be legend" теж має відмінне значення. При перекладі І. Стронговський вдається до модуляції, змінюючи значення слова "be" та використовує додавання. У ТП О. Леська спостерігаємо ідентичне до ТО речення, тому і значення його не змінюється. Стосовно останньої частини, можна зазначити, що використаний О. Леськом антонімічний переклад є більш вдалим, адже дослівний переклад І. Стронговського звучить доволі штучно і не до кінця передає задуманий автором ефект.

Bob's thick blond hair was what you get when hair cream calls itself sculpting mousse, so thick and blond and the part is so straight (Palahniuk, 2006, p. 16).

Густе світле волосся Боба показувало, що можна отримати, коли крем для волосся зветься мусом для укладання волосся, - таке густе, світле й частково випрямлене (Палагнюк, 2007, с. 11).

Поглянувши на його волосся - густюще, біляве, з неприродно прямим проділом, - можна побачити, що буде, коли переборщити з кремом для укладання зачіски (Поланік, 2017, с. 16).

Порівнявши два переклади цього речення, одразу ж можна помітити разючу відмінність у їх смислах. Так, дослівний переклад виконаний I. Стронговським заплутує читача і видається складним для розуміння. Водночас О. Лесько міняє структуру речення, вдається до модуляції, розширюючи або змінюючи значення певних слів. Саме тому його варіант легше сприймається реципієнтом.

У своєму романі Чак Поланік використовує безліч коротких простих речень для передачі уривчастості сприйняття героєм дійсності. Таким чином читачу легше уявити ситуацію зі сторони персонажа. 3 іншого боку, ці речення слугують для різкого переходу між діями. До прикладу:

The warm hand is cupped under you. The cold tip of the knife.

An arm wraps around your chest.

Therapeutic physical contact.

Hug time.

And the ether presses your nose and mouth, hard.

Then nothing, less than nothing. Oblivion (Palahniuk, 2006, p. 191).

Тепла рука під тобою складена чащечкою. Холодний кінчик ножа. Рука

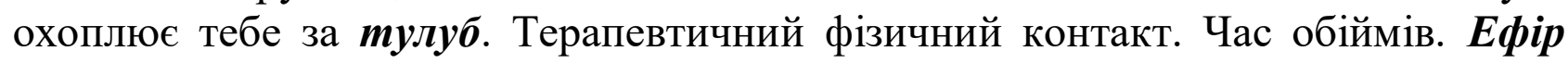
щільно притискають тобі до носа й рота. А потім - нічого, менше ніж нічого. Забуття (Палагнюк, 2007, с. 293).

Тепла, стиснута в кулак рука під тобою. Холодний кінчик ножа.

Рука охоплює твоє огруддя. 
Терапевтичний фізичний контакт.

Час обіймів.

Ганчірка, змочена ефіром, щільно притискається тобі до носа й до рота.

А тоді - ніщо, ба гірше, ніж ніщо. Небуття (Поланік, 2017, с. 222).

У цьому прикладі найперша відмінність, яка одразу ж привертає увагу структура тексту. І. Стронговський, на відміну від О. Леська, не дотримується структури, присутньої в ТО. Всі речення у його інтерпретації поєднані у суцільний абзац.

Розглянувши відмінності перекладу на лексичному рівні, бачимо, що при перекладі "hand is cupped" О. Лесько використовує модуляцію, що дещо змінює загальне сприйняття описаних подій.

При перекладі слова "chest" І. Стронговський вдається до генералізації, замінюючи видове значення на родове "тулуб". У наступному реченні О. Лесько застосовую декомпресію задля адекватності перекладу, тому "ether" у його варіації - "ганчірка, змочена ефіром".

При перекладі односкладного іменникового речення "Oblivion", яке означає "стан забуття чи ігнорування" (https://www.thefreedictionary.com/), перекладачі обирають слова, які звучать дещо схоже, проте мають різні значення. Так, забуття - це "втрата згадки про кого-, що-небудь", тоді як небуття - "стан, коли припиняється існування. життя, буття" (http://sum.in.ua/). Зважаючи на це, у даному випадку доцільніше використання слова "забуття".

До того ж, характерним для письменницького стилю Поланіка $є$ імітація розмовного стилю мови:

Big Bob says, "The first rule in Project Mayhem is you don't talk- "I cut him off. I say, yeah. Yeah, yeah, yeah, yeah, yeah (Palahniuk, 2006, p. 131).

Великий Боб каже: "Перше правило проекту "Каліцтво" - ти не говориш..."

Я обриваю його на півслові. Ага, кажсу. Так, так, так, так, так (Палагнюк, 2007, с. 200).

Великий Боб відповідає:

- Перше правило проекту "Руїна" - не роз...

Я перепиняю його. Ага, каэсу я, знаю. Знаю, знаю, знаю, знаю. (Поланік, 2017, c. 154).

У оригінальному фрагменті бачимо типові для англійської мови розмовні фрази, які дають читачеві можливість сприймати розмову природно. У обох ТП спостерігаємо дотримання стилю завдяки використанню звичних розмовних слів, що передає задуманий автором ефект.

Висновки. Головною причиною варіативності перекладу можна вважати різні інтерпретації перекладачами одного і того ж тексту оригіналу, що, зі свого боку, охоплює не лише розуміння оригінального змісту твору, а й перекладацьку позицію самого перекладача.

У процесі дослідження було встановлено, що від того, як перекладач інтерпретуватиме текст оригіналу та наскільки адекватно передасть його суть $\mathrm{i}$ чи зможе зберегти стиль автора, залежатиме сприйняття та розуміння твору реципієнтами тієї культури, на яку здійснено переклад. 
Перспективи дослідження вбачаємо в подальшому визначенні оптимальних шляхів для рецепції перекладу та у виявленні варіативності тактик, застосованих перекладачами у процесі роботи над творами різних жанрів.

\section{Список літератури}

Богин Г. И. Рефлективность и импульсивность в коммуникации. Культура общения и ее формирование. Воронеж. 1996. С. 2-5.

Еко У. Роль читача. Дослідження з семіотики текстів / пер. з іт. М. Гірняк. Львів : Літопис, 2004. 385 с.

Кашкин В. Б. Асимметричность знака и межъязыковые различия. Теоретические проблемы современного языкознания. Воронеж. 2009. С. 32-37.

Кубатченко О. Что скрывается за понятием «трансгрессивная литература»? Школп жизни.ру https://shkolazhizni.ru/culture/articles/15397/ (дата звернення: 23.02.2021).

Минченков А. Г. Когниция и эвристика в процессе переводческой деятельности. СанктПетербург : Антология, 2007. 256 с.

Павиленис Р. И. Проблемы смысла: современный логико-философский анализ языка. Москва : Мысль, 1983. 286 с.

Палагнюк Ч. Бійцівський клуб / пер. з англ. І. Стронговського. Харків : Фоліо, 2007. 318 с.

Поланік Ч. Бійцівський клуб / пер. з англ. О. Леська. Харків : Клуб сімейного дозвілля, 2017. 256 с.

Ревзин И. И., Розенцвейг В. Ю. Основы общего и машинного перевода. Москва : Высшая школа, 1964. $243 \mathrm{c.}$

Рильський М. Т. Мистецтво перекладу. Київ : Радянський письменник, 1975. 344 с.

Розенцвейг В. Ю. Журнал канадских переводчиков МЕТА. Тетради переводчика. 1983. 20. С. 91-102.

Словник української мови. URL: http://sum.in.ua/ (дата звернення: 23.02.2021).

Швейцер А. Д. Перевод и лингвистика. (Газетно-информационный и военно-публицистический перевод). Москва : Воениздат, 1973. 280 с.

Bialyk V. D. Fundamentals of Translation Theory. Chernivtsi: Chernivetskyi nats. un-t. 2016. 376 p.

Chuck Palahniuk Interviewed on Stage at Cafe du Nord on May 20, 2010. The Agony Column. URL: http://bookotron.com/agony/news/2011/01-24-11-podcast.htm\#podcast012711 (Last accessed: 23.02.2021).

It's Paula-nick. The Guardian. URL: https://www.theguardian.com/books/2004/mar/24/fiction. chuckpalahniuk (Last accessed: 23.02.2021).

Newmark P. Round-table Discussion on Translation in the NewMilennium. Translation Today: Trends and Perspectives. Clevedon : Multilingual Matters Ltd., 2003. P. 13-67.

Palahniuk Ch. Fight Club. London : VintageBooks, 2006. 224 p.

The Free Dictionary by Farlex. URL: https://www.thefreedictionary.com/ (Last accessed: 23.02.2021).

\section{References}

Bogin, G. I. (1996). Reflektivnost` i impul'sivnost` v kommunikaczii [Reflexivity and impulsivity in communication]. Kul tura Obshheniya i yeyo Formirovanie, 2-5.

Bialyk, V. D. (2016). Fundamentals of Translation Theory. Chernivtsi: Chernivetskyi nats. un-t.

Eko, U. (2004). Rol chytacha. Doslidzhennia z semiotyky tekstiv. [The role of the reader. Research on the semiotics of texts]. (M. Hirniak, Trans.). Lviv: Litopys.

Kashkin, V. B. (2009). Asimmetrichnost`znaka i mezh yazy`kovy`e razlichiya [Sign asymmetry and language differences]. Teoreticheskie Problemy`Sovremennogo Yazy`koznaniya. Sbornik v Chest` Prof.Z.D. Popovoj, 32-37.

Kleffel, R. (2011). Chuck Palahniuk Interviewed on Stage at Cafe du Nord on May 20, 2010. Retrieved from http://bookotron.com/agony/news/2011/01-24-11-podcast.htm\#podcast012711.

Kubatchenko, O. (2008). Chto skry`vaetsya za ponyatiem «transgressivnaya literatura»? [What is hidden behind the concept of "transgressive literature"?] Shkola zhizni.ru. Retrieved from https://shkolazhizni.ru/culture/articles/15397/.

Minchenkov, A. G. (2007). Kognicziya i èvristika v proczesse perevodcheskoj deyatel'nosti [Cognition and heuristics in the process of translation]. Sankt-Peterburg: Antologiya.

Nebuttia. (n.d.). In Slovnyk ukrainskoi movy [Dictionary of the Ukrainian language]. Retrieved February 23, 2021, from http://sum.in.ua/.

Newmark, P. (2003). Round-table Discussion on Translation in the New Milennium. Translation Today: Trends and Perspectives, 13-67. https://pdfslide.tips/documents/-pdf55cf9acc550346d033a372a7.html. 
Oblivion. (n.d.). In The Free Dictionary by Farlex. Retrieved February 23, 2021, from https://www.thefreedictionary.com.

Palahniuk, Ch. (2007). Biitsivskyi klub [Fight club]. (I. Strongovskyi, Trans.). Kharkiv: Folio..

Palahniuk, Ch. (2006). Fight Club. London: VintageBooks.

Pavilenis, R. I. (1983). Problemy`smy`sla: sovremenny`j logiko-filosofskij analiz yazy `ka [Problems of meaning: modern logical-philosophical analysis of language]. Moskva: My`sl`. dozvillia.

Polanik, Ch. (2017). Biitsivskyi klub [Fight club]. (O. Lesko, Trans.). Kharkiv: Klub simeinoho

Revzin, I. I., \& Rozenczvejg, V. Yu. (1964). Osnovy`obshhego i mashinnogo perevoda [Fundamentals of General and Machine Translation.]. Moskva: Vy`sshaya shkola.

Rozenczvejg, V. Yu. (1983). Zhurnal kanadskikh perevodchikov META [Canadian Translators Journal META]. Tetradi Perevodchika, 20, 91-102.

Rylskyi, M. T. (1975). Mystetstvo perekladu [The art of translation]. Kyiv: Radianskyi pysmennyk.

Shvejczer, A. D. (1973). Perevod i lingvistika. (Gazetno-informaczionny j $i$ voenno-publiczisticheskij perevod) [Translation and linguistics. (Newspaper informational and military journalistic translation)]. Moskva: Voenizdat.

The Guardian (2004). It's Paula-nick. Retrieved from https://www.theguardian.com/books/2004/mar/ 24/fiction.chuckpalahniuk.

Zabuttia. (n.d.). In Slovnyk ukrainskoi movy [Dictionary of the Ukrainian language]. Retrieved February 23, 2021, from http://sum.in.ua/.

УДК 316.1:800.86:33

\title{
MECHANISMS OF ORTHODONTIC TERMS CREATION IN ENGLISH LANGUAGE СЛОВОТВІРНІ МЕХАНІЗМИ ГЕНЕЗИ ОРТОДОНТИЧНИХ ТЕРМІНІВ У АНГЛІЙСЬКІЙ МОВІ
}

\author{
Каріна КАРАТІНЦЕВА \\ Буковинський державний медичний університет \\ karatintsevak@gmail.com \\ ORCID ID 0000-0002-3093-5013
}

The study of terminology and lexical fields of specialized lexis is an important issue in linguistics. Special attention should be devoted to the medical terminology, which branches into different areas, is heterogeneous in its composition and has specific properties and patterns. The article is devoted to the classification and structural analysis of orthodontic English terminological units.

The objective of the article is to study the main word-forming mechanisms of orthodontic terms in English, their classification, characteristics, and comparison. The research is based on methods of analysis, synthesis and comparison of terminological units of English orthodontic text (scientific articles, monographs and textbooks). Using structural analysis, English orthodontic terms were classified according to the methods of their creation. The field of terminology "Orthodontics" is classified and divided into 4 categories: "Anatomy of the Oral Cavity", "Symptoms and Diseases", "Professional Orthodontic Activity" and "Treatments". It is determined that the most common wordforming means are morphological and terminological phrases, which are characteristic to most categories. A lot of the lexical units of the category "Anatomy of the Oral Cavity" are borrowed from Latin and Greek or contain word-forming affixes. The category "Symptoms and Diseases" contains a lot of phrases. A special feature of "Professional Orthodontic Activity" is the graphic units of the written orthodontic text, which are formed by abbreviations and combined abbreviations. "Treatments" are characterized by abbreviations and combined abbreviations. 